\title{
The effect of dietary supplementation with Saccharomyces cerevisiae dried yeast on lambs meat quality
}

\author{
S. Milewski ${ }^{1}$ and B. Zaleska \\ University of Warmia and Mazury in Olsztyn, \\ Department of Sheep and Goat Breeding, Faculty of Animal Bioengineering \\ Oczapowskiego 5, 10-719 Olsztyn
}

(Received 21 April 2010; revised version 21 October 2011; accepted 6 December 2011)

\begin{abstract}
The effect of supplementary dried brewer's yeast, Saccharomyces cerevisiae, during 100 days rearing period on meat quality of lambs was investigated. Twenty four male Kamieniecka breed lambs were divided into two groups: I - control, II - experimental - supplemented with preparate Inter Yeast ${ }^{\mathbb{B}} \mathrm{S}$, containing Saccharomyces cerevisiae.

Meat quality was determined on samples of M. longissimus lumborum (LL) and M. quadriceps femoris $(\mathrm{QF})$, based on the following parameters: chemical composition, physicochemical properties, the fatty acid composition and profile of intramuscular fat, and sensory properties. Meat of lambs from group II contained more dry matter $(0.78 \%)$ and intramuscular fat $(0.33 \%)$, compared with control lambs $(\mathrm{P}<0.01)$. An increase the red colour component $a^{*}(\mathrm{P}<0.01)$ and improvement the waterholding capacity $(\mathrm{P}<0.01)$ of meat were also found in the experimental group. The concentrations of $\mathrm{C}_{14: 1}, \mathrm{C}_{18: 2}$ and $\mathrm{C}_{22: 6}$ fatty acids $(\mathrm{P}<0.05)$ and conjugated linoleic acid $\mathrm{C}_{18: 2}$ cis 9 trans 11 were higher $(\mathrm{P}<0.01)$ and the content of $\mathrm{C}_{20: 4}$ was lower $(\mathrm{P}<0.01)$ in the intramuscular fat of lambs from group II. The above changes had no influence on the sensory properties of meat. The content of dry matter and protein was higher, and cooking loss was lower $(\mathrm{P}<0.001)$ in LL than in QF muscle. The sensory properties were better in QF muscle.
\end{abstract}

KEY WORDS: lambs, brewer's yeast, prebiotic, meat quality

\section{INTRODUCTION}

Lamb meat is lean, easily digestible and assimilable, it has a high nutritional value (Kłobukowski et al., 2002) and health-promoting properties (Milewski,

\footnotetext{
${ }^{1}$ Corresponding author: e-mail: stanislaw.milewski@uwm.edu.pl
} 
2006). Lamb meat has a desirable amino acid composition (Jandásek et al., 2003; Brzostowski and Tański, 2006) and amino acid profile of intramuscular fat (Brzostowski and Tański, 2006), as well as a high content of functional components (Patkowska-Sokoła et al., 2000). It is also a rich source of minerals and vitamins (Milewski, 2006). Meat with superior health benefits is obtained when lambs are fed rations based on organic feed. However, such systems are characterized by a slower growth rate of animals and lower production effectiveness. Therefore, attempts are made to supplement lamb diets with natural stimulators (Collins and Ribson, 1999), including yeast Saccharomyces cerevisiae, which has a wide spectrum of activity (Lyons, 2001). Dried yeast supplements are more comprehensive for dietary purposes due to broader distribution, storage and application. Depending on production technology, they can be administered in the form of a probiotic containing live cells or a prebiotic comprising dead cells (Dobicki et al., 2007). Milewski's studies (2009) support the use of dried yeast (Saccharomyces cerevisiae) with prebiotic properties in lamb feeding, the administration of Inter Yeast ${ }^{\circledR} S$ mixed with concentrate stimulated the growth rate and muscle development in suckling lambs. However, none of the studies conducted to date examined the influence of dried yeast on lamb meat quality. Titi et al. (2007) reported significant changes in the chemical composition of meat (an increase in fat content and a decrease in protein content) from lambs fed diets supplemented with live yeast cultures (Diamond V).

The objective of this study was to determine the effect of supplementing the concentrate fed to suckling lambs with prebiotic preparate of Saccharomyces cerevisiae dried brewer's yeast on meat quality.

\section{MATERIAL AND METHODS}

\section{Animals, diets and sampling}

The experimental materials comprised meat samples collected from 24 male Kamieniecka breed lambs aged 100 days. The lambs were divided into two groups: a control (I) and an experimental (II), with similar body weight (determined on the second day of life: group I - $5.22 \mathrm{~kg}$, group II $-5.18 \mathrm{~kg}$ ) and the age of ewes (3-4 years old), to eliminate the differences in milk yield. During the 100-day rearing period a uniform feeding regime was applied in both groups, including ewes and lambs. Lambs were fed diets composed of meadow hay, hay silage of grass and legumes and CJ concentrate. Nutritive value of feeds, using INRA system (1988), were calculated using a computer program WINWAR. Dry matter content in hay silage, meadow hay and CJ concentrate was: $44.26,83.95$ and $88.65 \%$, 
respectively. UFV and crude protein content in feed were respectively: 0.81 and $181.88 \mathrm{~g}$ in hay silage, 0.66 and $89.34 \mathrm{~g}$ in meadow hay, 1.106 and $169.32 \mathrm{~g}$ in CJ concentrate. The lambs from group II received the supplement Inter Yeast ${ }^{\mathbb{}} \mathrm{S}$, prebiotic preparate, containing dried brewer's yeast (Saccharomyces cerevisiae). The prebiotic was mixed with CJ concentrate in the proportion of $50 \mathrm{~g} / \mathrm{kg} \mathrm{CJ}$ concentrate, identical for both groups, and was increased every 10 days by 0.05 $\mathrm{kg} / \mathrm{animal} /$ day, starting from $0.05 \mathrm{~kg} / \mathrm{animal} /$ day at the age of $11-20$ days. The quantity of the administered feed and refusals were monitored throughout the experiment, and their chemical composition was analysed according to standard methods (AOAC, 1990) to determine nutrient intake throughout the experiment.

Lambs were slaughtered at the age of 100 days. Average body weight at the end of experiment was $23.55 \mathrm{~kg}$ in group I and $28.65 \mathrm{~kg}$ in group II. After slaughter carcasses were chilled at $4^{\circ} \mathrm{C}$ for $18-24 \mathrm{~h}$ and then the $M$. longissimus lumborum (LL) and M. quadriceps femoris (QF) of the right half-carcass were separated.

\section{Meat quality determination}

Meat quality was evaluated based on the following parameters: chemical composition, physicochemical properties, the fatty acid composition and profile of intramuscular fat, and sensory properties. The proximate chemical composition of meat was determined according to standard methods (AOAC, 1990). The following physicochemical properties of meat were measured: $\mathrm{pH}_{24}-24 \mathrm{~h}$ postmortem, using a Double Pore glass-combination electrode (Hamilton) and a 340i pH-meter, colour parameters $L^{*}, a^{*}$ and $b^{*}$ - by the reflectance method, using a MiniScan XE Plus spectrophotometer (HunterLab), water-holding capacity - by the Grau-Hamm method (Oeckel et al., 1999), natural drip loss and cooking loss - by the Honikel method (1998). The fatty acid composition of intramuscular fat was determined by esterification (Peisker, 1964) followed by gas chromatography using a VARIAN CP-3800 chromatograph. Separation parameters were as follows: a flame ionization detector FID, capillary column - length: $50 \mathrm{~m}$, inner diameter: $0.25 \mathrm{~mm}$, liquid phase - CP-Sil 88, film thickness - $0.25 \mu \mathrm{m}$, carrier gas - helium, carrier gas flow rate $-1.2 \mathrm{ml} / \mathrm{min}$. The sensory properties of cooked meat, including aroma (intensity and desirability), taste (intensity and desirability), juiciness and tenderness were evaluated by five trained panelists on a five-point scale, using calibration methods. Shear force of meat was determined after thermal treatment, as described by Honikel (1998), using a Warner-Bratzler head (500 N) attached to an INSTRON universal testing machine (model 5542), on cylindrical samples with a diameter of $1.27 \mathrm{~cm}$ and height of $2 \mathrm{~cm}$. 


\section{Statistical analysis}

The results were performed statistically by a two-factorial analysis of variance in an orthogonal design. The significance of differences between groups was verified with Duncan's test. The calculations were performed using Statistica 8.0 StatSoft Inc. software.

\section{RESULTS}

The feed intake by lambs in both groups were similar, about $530 \mathrm{~kg}$ of dry matter, $65 \mathrm{~kg}$ crude protein, $114 \mathrm{~kg}$ crude fibre, $39 \mathrm{~kg}$ UFV, $41 \mathrm{~kg}$ PDIN and $43 \mathrm{~kg}$ PDIE.

No significant differences in feed consumption were observed between the groups during the experiment. Only small amounts of hay silage were sporadically left, which suggests that nutrient intake was similar in both groups.

The chemical composition and physicochemical properties of meat are presented in Table 1. Meat from group II lambs contained more dry matter and intramuscular fat compared with control lambs $(\mathrm{P}<0.01)$. Significant differences were also found between the groups as regards the colour parameters and water-holding capacity of meat. Meat from group II lambs was characterized by a lower value of colour component $L^{*}$, a higher value of component $a^{*}$ $(\mathrm{P}<0.01)$, and a higher water-holding capacity $(\mathrm{P}<0.01)$. Muscle type had a significant effect on the investigated traits. The LL muscle had a higher content

Table 1. Chemical composition and physicochemical properties of meat

\begin{tabular}{|c|c|c|c|c|c|}
\hline \multirow{2}{*}{ Parameter } & \multicolumn{2}{|c|}{ Group } & \multicolumn{2}{|c|}{ Muscle $^{1}$} & \multirow{2}{*}{ eraction } \\
\hline & I & II & LL & $\mathrm{QF}$ & \\
\hline Dry matter, \% & $23.87^{\mathrm{B}} \pm 0.81$ & $24.65^{\mathrm{A}} \pm 0.63$ & $24.66^{\mathrm{A}} \pm 0.67$ & $23.86^{\mathrm{B}} \pm 0.77$ & ns \\
\hline Protein, \% & $20.54 \pm 0.65$ & $20.76 \pm 0.61$ & $20.99^{\mathrm{A}} \pm 0.58$ & $20.32^{\mathrm{B}} \pm 0.50$ & ns \\
\hline Fat, \% & $2.00^{\mathrm{B}} \pm 0.11$ & $2.33^{\mathrm{A}} \pm 0.33$ & $2.10 \pm 0.20$ & $2.23 \pm 0.36$ & ns \\
\hline Ash, \% & $1.08 \pm 0.04$ & $1.06 \pm 0.04$ & $1.07 \pm 0.05$ & $1.07 \pm 0.05$ & ns \\
\hline $\mathrm{pH}_{24}$ & $5.63 \pm 0.06$ & $5.63 \pm 0.08$ & $5.59^{\mathrm{B}} \pm 0.04$ & $5.67^{\mathrm{A}} \pm 0.07$ & ns \\
\hline Water : protein ratio & $3.70 \pm 0.15$ & $3.63 \pm 0.13$ & $3.59^{\mathrm{B}} \pm 0.13$ & $3.74^{\mathrm{A}} \pm 0.12$ & ns \\
\hline \multicolumn{6}{|l|}{ Colour: } \\
\hline$L^{*}$ & $48.48^{\mathrm{A}} \pm 2.58$ & $46.01^{\mathrm{B}} \pm 2.30$ & $47.76 \pm 2.61$ & $46.73 \pm 2.80$ & ns \\
\hline$a^{*}$ & $11.14^{\mathrm{B}} \pm 0.69$ & $12.28^{\mathrm{A}} \pm 0.77$ & $11.60 \pm 0.95$ & $11.82 \pm 0.90$ & ns \\
\hline$b^{*}$ & $14.44 \pm 0.85$ & $14.23 \pm 0.72$ & $14.22 \pm 0.70$ & $14.44 \pm 0.86$ & ns \\
\hline Water-holding capacity, $\mathrm{cm}^{2}$ & $18.06^{\mathrm{A}} \pm 2.24$ & $16.25^{\mathrm{B}} \pm 2.01$ & $16.88 \pm 2.09$ & $17.44 \pm 2.50$ & ns \\
\hline Cooking loss, $\%$ & $37.38 \pm 4.54$ & $37.48 \pm 2.15$ & $35.81^{\mathrm{B}} \pm 3.43$ & $39.05 \pm 2.79$ & ns \\
\hline Drip loss, $\%$ & $1.36 \pm 0.37$ & $1.18 \pm 0.25$ & $1.32 \pm 0.27$ & $1.22 \pm 0.37$ & ns \\
\hline
\end{tabular}


of dry matter and protein, but lower values of $\mathrm{pH}, \mathrm{W} / \mathrm{P}$ ratio and cooking loss $(\mathrm{P}<0.01)$. The applied yeast supplement significantly affected the levels of fatty acids in intramuscular fat (Table 2). The concentrations of $\mathrm{C}_{14: 1}, \mathrm{C}_{18: 2}$ and $\mathrm{C}_{22: 6}$ fatty acids $(\mathrm{P}<0.05)$ and conjugated linoleic acid $\mathrm{C}_{18: 2}$ cis 9 trans 11 were higher $(\mathrm{P}<0.01)$, and the content of $\mathrm{C}_{20: 4}$ was lower $(\mathrm{P}<0.01)$ the intramuscular fat of lambs from group II. The fat of the LL muscle contained more $\mathrm{C}_{18: 0}$ fatty acid in comparison with the $\mathrm{QF}$ muscle $(\mathrm{P}<0.05)$. The fatty acid profile was similar in both muscles and in both groups (Table 3 ). No significant interactions between the experimental factors were found for any of the above traits.

Table 2. Fatty acid composition of intramuscular fat, $\%$

\begin{tabular}{|c|c|c|c|c|c|}
\hline \multirow[b]{2}{*}{ Fatty acids } & \multicolumn{2}{|c|}{ Group } & \multicolumn{2}{|c|}{ Muscle } & \multirow[b]{2}{*}{ Interaction } \\
\hline & I & II & LL & QF & \\
\hline$\overline{\mathrm{C}_{10: 0}}$ & $0.28 \pm 0.06$ & $0.31 \pm 0.11$ & $0.31 \pm 0.09$ & $0.29 \pm 0.09$ & ns \\
\hline $\mathrm{C}_{12: 0}^{10: 0}$ & $0.77 \pm 0.17$ & $0.75 \pm 0.27$ & $0.75 \pm 0.21$ & $0.77 \pm 0.24$ & ns \\
\hline $\mathrm{C}_{14: 0}^{12: 0}$ & $6.08 \pm 0.72$ & $6.16 \pm 1.31$ & $6.13 \pm 1.13$ & $6.11 \pm 0.98$ & ns \\
\hline $\mathrm{C}_{15: 0}^{14.0}$ & $0.73 \pm 0.07$ & $0.70 \pm 0.11$ & $0.71 \pm 0.10$ & $0.72 \pm 0.09$ & ns \\
\hline $\mathrm{C}_{16: 0}^{15: 0}$ iso & $0.23 \pm 0.02$ & $0.25 \pm 0.03$ & $0.25 \pm 0.04$ & $0.24 \pm 0.03$ & ns \\
\hline $\mathrm{C}_{16: 0}^{10.0}$ & $26.87 \pm 0.92$ & $26.00 \pm 1.54$ & $26.40 \pm 1.27$ & $26.47 \pm 1.42$ & ns \\
\hline $\mathrm{C}_{17.0}^{100}$ & $1.33 \pm 0.06$ & $1.31 \pm 0.06$ & $1.34 \pm 0.06$ & $1.30 \pm 0.06$ & ns \\
\hline $\mathrm{C}_{18: 0}^{17.0}$ & $15.93 \pm 1.01$ & $16.14 \pm 1.29$ & $16.50^{\mathrm{a}} \pm 1.24$ & $15.57^{b} \pm 0.83$ & ns \\
\hline $\mathrm{C}_{20: 0}^{10.0}$ & $0.16 \pm 0.02$ & $0.15 \pm 0.03$ & $0.16 \pm 0.03$ & $0.15 \pm 0.02$ & ns \\
\hline $\mathrm{C}_{22: 0}^{20.0}$ & $0.11 \pm 0.03$ & $0.10 \pm 0.03$ & $0.11 \pm 0.03$ & $0.10 \pm 0.03$ & ns \\
\hline $\mathrm{C}_{12: 1}^{22.0}$ & $0.02 \pm 0.01$ & $0.02 \pm 0.01$ & $0.02 \pm 0.01$ & $0.02 \pm 0.01$ & ns \\
\hline $\mathrm{C}_{14: 1}^{12.1}$ & $0.19^{b} \pm 0.03$ & $0.22^{a} \pm 0.19$ & $0.20 \pm 0.04$ & $0.20 \pm 0.04$ & ns \\
\hline $\mathrm{C}_{16: 1}^{14.1}$ & $1.45 \pm 0.14$ & $1.47 \pm 0.05$ & $1.44 \pm 0.17$ & $1.49 \pm 0.16$ & ns \\
\hline $\mathrm{C}_{17: 1}^{10.1}$ & $1.09 \pm 0.07$ & $1.10 \pm 3.07$ & $1.09 \pm 0.05$ & $1.10 \pm 0.07$ & ns \\
\hline $\mathrm{C}_{18: 1}^{17.1}$ & $38.63 \pm 2.03$ & $38.85 \pm 0.02$ & $38.41 \pm 2.29$ & $39.08 \pm 2.85$ & ns \\
\hline $\mathrm{C}_{20: 1}$ & $0.10 \pm 0.01$ & $0.11 \pm 0.82$ & $0.11 \pm 0.01$ & $0.10 \pm 0.02$ & ns \\
\hline $\mathrm{C}_{18.2}^{2.12}$ & $3.68^{b} \pm 0.31$ & $4.15^{a} \pm 0.03$ & $3.89 \pm 0.82$ & $3.94 \pm 0.47$ & ns \\
\hline $\mathrm{C}_{18: 2}^{10.2}$ cis 9 trans 11 & $0.12^{\mathrm{B}} \pm 0.02$ & $0.15^{\mathrm{A}} \pm 0.09$ & $0.13 \pm 0.02$ & $0.14 \pm 0.03$ & ns \\
\hline $\mathrm{C}_{18: 3}^{10.2}$ & $0.84 \pm 0.12$ & $0.85 \pm 0.01$ & $0.83 \pm 0.10$ & $0.86 \pm 0.12$ & ns \\
\hline$C_{20: 2}$ & $0.03 \pm 0.01$ & $0.03 \pm 0.18$ & $0.03 \pm 0.01$ & $0.03 \pm 0.01$ & Ns \\
\hline $\mathrm{C}_{20: 4}^{20.2}$ & $1.11^{\mathrm{A}} \pm 0.13$ & $0.88^{\mathrm{B}} \pm 0.07$ & $0.96 \pm 0.15$ & $1.02 \pm 0.23$ & ns \\
\hline$C_{20: 5}$ & $0.14 \pm 0.05$ & $0.15 \pm 0.05$ & $0.13 \pm 0.04$ & $0.16 \pm 0.07$ & ns \\
\hline $\mathrm{C}_{22: 6}$ & $0.10^{b} \pm 0.04$ & $0.14^{a} \pm 0.05$ & $0.12 \pm 0.04$ & $0.12 \pm 0.05$ & ns \\
\hline
\end{tabular}

A,B - P $\leq 0.01 ;$;, $\mathrm{b}$ - $\mathrm{P} \leq 0.05 ;$ ns - not significant; ${ }^{1}$ see Table 1

The analysis of the sensory properties of meat revealed a significant effect of muscle type (Table 4). The score of aroma (intensity and desirability) and taste (intensity and desirability) was higher $(\mathrm{P} \leq 0.05)$ in $\mathrm{QF}$ than in LL muscle. Average shear force was by $3.82 \mathrm{~N}$ higher for the LL muscle $(\mathrm{P} \leq 0.05)$. Significant interactions between the experimental factors were found with respect to this parameter $(\mathrm{P} \leq 0.05)$ only for the LL muscle in the experimental group. 
Table 3. Fatty acid profile of intramuscular fat

\begin{tabular}{|c|c|c|c|c|c|}
\hline \multirow{2}{*}{ Specification } & \multicolumn{2}{|c|}{ Group } & \multicolumn{2}{|c|}{ Muscle $^{1}$} & \multirow{2}{*}{ Interaction } \\
\hline & I & II & LL & $\mathrm{QF}$ & \\
\hline$\overline{\text { SFA, } \%}$ & $52.50 \pm 2.07$ & $51.89 \pm 2.80$ & $52.62 \pm 2.25$ & $51.74 \pm 2.61$ & ns \\
\hline MUFA, \% & $41.49 \pm 2.05$ & $41.77 \pm 3.04$ & $41.26 \pm 2.20$ & $42.00 \pm 2.88$ & $\mathrm{~ns}$ \\
\hline PUFA, \% & $6.01 \pm 0.48$ & $6.34 \pm 1.05$ & $6.09 \pm 0.91$ & $6.27 \pm 0.74$ & ns \\
\hline UFA, $\%$ & $47.50 \pm 2.07$ & $48.11 \pm 2.80$ & $47.35 \pm 2.25$ & $48.26 \pm 2.61$ & ns \\
\hline UFA:SFA & $0.91 \pm 0.07$ & $0.93 \pm 0.11$ & $0.90 \pm 0.08$ & $0.94 \pm 0.10$ & ns \\
\hline PUFA:MUFA & $0.15 \pm 0.01$ & $0.15 \pm 0.03$ & $0.15 \pm 0.02$ & $0.15 \pm 0.02$ & ns \\
\hline PUFA:SFA & $0.12 \pm 0.01$ & $0.12 \pm 0.02$ & $0.12 \pm 0.02$ & $0.12 \pm 0.01$ & ns \\
\hline DFA, $\%$ & $63.43 \pm 1.74$ & $64.25 \pm 3.14$ & $64.85 \pm 2.58$ & $63.84 \pm 2.57$ & ns \\
\hline OFA, $\%$ & $36.57 \pm 1.74$ & $35.74 \pm 3.14$ & $36.15 \pm 2.58$ & $36.16 \pm 2.57$ & ns \\
\hline DFA:OFA & $1.74 \pm 0.13$ & $1.82 \pm 0.26$ & $1.78 \pm 0.21$ & $1.78 \pm 0.20$ & ns \\
\hline PUFA n $6, \%$ & $4.93 \pm 0.36$ & $5.21 \pm 0.92$ & $5.01 \pm 0.83$ & $5.13 \pm 0.56$ & ns \\
\hline PUFA n $3, \%$ & $1.08 \pm 0.15$ & $1.14 \pm 0.19$ & $1.08 \pm 0.14$ & $1.14 \pm 0.20$ & $\mathrm{~ns}$ \\
\hline PUFA n6:PUFA n3 & $4.60 \pm 0.44$ & $4.61 \pm 0.62$ & $4.67 \pm 0.64$ & $4.54 \pm 0.40$ & ns \\
\hline
\end{tabular}

ns - not-significant; SFA - saturated fatty acids; MUFA - monounsaturated fatty acids; PUFA polyunsaturated fatty acids; UFA - unsaturated fatty acids; DFA (UFA $\left.+\mathrm{C}_{18: 0}\right)$ - dietary fatty acids having desirable (either neutral or hypocholesterolemic) effect in humans; OFA (SFA - C ${ }_{18: 0}$ ) dietary fatty acids having objectionable (hypercholesterolemic) effect in humans; PUFA n6 (C $+\mathrm{C}_{18: 2}$ cis 9 trans $\left.11+\mathrm{C}_{20: 2}+\mathrm{C}_{20: 4}\right)$; UFA n3 $\left(\mathrm{C}_{18: 3}+\mathrm{C}_{20: 5}+\mathrm{C}_{20: 6}\right) ;{ }^{1}$ see Table 1

Table 4. Sensory properties (points) and shear force $(\mathrm{N})$ of meat

\begin{tabular}{|c|c|c|c|c|c|}
\hline \multirow{3}{*}{ Traits } & \multicolumn{2}{|c|}{ Group } & \multicolumn{2}{|c|}{ Muscle } & \multirow{3}{*}{ Interaction } \\
\hline & I & II & LL & $\mathrm{QF}$ & \\
\hline & mean & mean & mean & mean & \\
\hline Aroma intensity & $4.50 \pm 0.32$ & $4.66 \pm 0.35$ & $4.44^{b} \pm 0.36$ & $4.72^{\mathrm{a}} \pm 0.26$ & $\mathrm{~ns}$ \\
\hline Aroma desirability & $4.50 \pm 0.32$ & $4.66 \pm 0.35$ & $4.44^{b} \pm 0.36$ & $4.72^{\mathrm{a}} \pm 0.26$ & ns \\
\hline Taste intensity & $4.22 \pm 0.36$ & $4.16 \pm 0.24$ & $4.06^{\mathrm{b}} \pm 0.31$ & $4.31^{\mathrm{a}} \pm 0.25$ & ns \\
\hline Taste desirability & $4.22 \pm 0.36$ & $4.16 \pm 0.24$ & $4.06^{\mathrm{b}} \pm 0.31$ & $4.31^{\mathrm{a}} \pm 0.25$ & $\mathrm{~ns}$ \\
\hline Tenderness & $4.19 \pm 0.31$ & $4.22 \pm 0.32$ & $4.28 \pm 0.32$ & $4.13 \pm 0.29$ & ns \\
\hline Juiciness & $4.19 \pm 0.36$ & $4.19 \pm 0.40$ & $4.28 \pm 0.36$ & $4.09 \pm 0.38$ & ns \\
\hline General evaluation & $4.30 \pm 0.24$ & $4.34 \pm 0.21$ & $4.26 \pm 0.24$ & $4.38 \pm 0.19$ & ns \\
\hline Shear force & $26.62 \pm 4.10$ & $26.50 \pm 5.81$ & $28.47^{a} \pm 4.60$ & $24.65^{b} \pm 4.65$ & * \\
\hline
\end{tabular}

$\mathrm{a}, \mathrm{b}$ - $\mathrm{P} \leq 0.05$; ns - not significant; * interaction significant at $\mathrm{P} \leq 0.05$

\section{DISCUSSION}

Meat from lambs of both group was high quality. The value of water to protein ratio was low, indicating a high degree of ripeness (Brzostowski and Tański, 2006), and $\mathrm{pH}_{24}$ from 5.5 to 5.9 considered optimal by Schieffer and Scharner (1977). The yeast supplement contributed to an increase in the fat content in meat. A similar effect was reported by Titi et al. (2007). It is a well known that the majority of consumers prefer lean meat. Intramuscular fat, as an integral component of meat, affects its sensory properties (Campo et al., 2003). However, the increase 
in fat content from 2.00 to $2.33 \%$ observed in the present study had no significant influence on sensory traits which remained high irrespective of the experimental factor. The increase of fat content could be considered desirable as it resulted in positive changes in the fatty acid composition of intramuscular fat, including an increase in the concentrations of linoleic acid $\mathrm{C}_{18: 2}$ and conjugated linoleic acid $\mathrm{C}_{18: 2}$ cis 9 trans 11, which are essential for health (Ulbricht and Southgate, 1991; Fritche and Steinhart, 1998). However, significant differences between groups were minor and could be a result of a small variation, hence it is difficult to unambiguously associate them with the influence of the yeast preparation. The noted changes in the concentrations of fatty acids had no significant effect on their profile, which was similar in both studied muscles. The health benefits of lamb meat analysed in the study should be stressed. The ratio between $n-6$ and $n-3$ polyunsaturated fatty acids was within the optimal range of 4-6:1. The described changes could result from the wide spectrum of yeast activity. According to Dobicki et al. (2005), yeast affects the structure of ruminal microbial populations, thus determining nutrient utilization. As suggested Titi et al. (2007), changes in the chemical composition of lamb meat may be correlated with the rate of rumen fermentation and metabolism of end products under the influence of yeast. Such changes, involving an increase in propionic acid production, were reported by, among others, Erasmus et al. (1992). It seems that the improvement in the health status of lambs fed a yeastsupplemented diet positively affected the course of metabolic processes (Milewski et al., 2007; Milewski and Sobiech, 2010). Such effect of prebiotics was also reported by Masanetz et al. $(2010,2011)$ who administered lactulose and inulin to calves. The results of those studies show a clear effect of prebiotics on certain parameters associated with animal health and performance, but effect differ between substances. In this respect an important role was played by the structural components of yeast cell walls, $\beta-1,3 / 1,6-\mathrm{D}$-glucan and mannanoligosaccharides (MOS) (Milewski et al., 2007). Meat from lambs received dried yeast had a higher water-holding capacity, i.e. the ability of muscle cells to retain water during heat treatment (Aaslyng et al., 2003; Micklander et al., 2005). A lower water-holding capacity is usually correlated with a lighter colour of meat. However, in this study the darker colour of meat from experimental lambs resulted most probably from a higher contribution of red colour component $a^{*}$. Those changes were small and would have no influence on consumer preferences. M. longissimus lumborum, in comparison with M. quadriceps femoris, had higher content of dry matter and protein, a higher degree of maturity and lower cooking loss. Sensory properties, aroma and taste, were better in M. quadriceps femoris. It was also more tender, as confirmed by the lower values of shear force which is an objective measure of tenderness. The difference between shear force and sensory evaluation confirms the opinion that both methods complete each other and should be performed simultaneously (Brzostowski et al., 2006). 


\section{CONCLUSIONS}

Supplementation of diet for lambs with dried yeast Saccharomyces cerevisiae, had a significant effect on the meat quality. The intramuscular fat content of meat increased, the fatty acid composition of intramuscular fat and the water-holding capacity of meat improved, and meat colour became darker. The above changes had no influence on the sensory properties of meat.

\section{REFERENCES}

Aaslyng M. D., Bejerholm C., Ertbjerg P., Bertram H. C., Andersen H.J., 2003. Cooking loss and juiciness of pork in relation to raw meat quality and cooking procedure. Food Qual. Preference $14,277-288$

AOAC, 1990. Association of Official Analytical Chemists, Official Methods of Analysis. $15^{\text {th }}$ Edition. Washington, DC

Brzostowski H., Niżnikowski R., Milewski S., 2006. Composition and properties of meat from Pomeranian purebred lambs and their crossbreeds with Berrichon du Cher and Charolaise. Arch. Tierzucht 49, 494-501

Brzostowski, H., Tański Z., 2006. Nutritional value of the meat of Pomeranian breed lambs and crossbreeds of Blackheaded and Texel rams. Arch. Tierzucht, Special Issue 49, 345-352

Campo M.M., Nute G.R., Wood J.D., Elmore S.J., Mottram D.S., Enser M., 2003. Modelling the effect of fatty acids in odour development of cooked meat in vitro: part I-sensory perception. Meat Sci. 63, 367-375

Collins M.D., Ribson G.R., 1999. Probiotics, prebiotics and symbiotics: approaches for modulatingthe microbial ecology of the gut. Amer. J. Clin. Nutr. 69, 1052S-1057S

Dobicki A., Preś J., Luzak W., Szyrner A., 2005. Influence of dried brewery's yeast on body weight gains, physiological and biochemical indicators of blood and development of the rumen microorganisms in calves. Med. wet. 61, 946-949

Dobicki A., Preś J., Zachwieja A., Mordak R., Jakus W., 2007. Influence of yeast preparations on chosen biochemical blood parameters and the composition of cow milk Med. wet. 63, 955-959

Erasmus L.J., Botha P.M., Kistner A., 1992. Effect of yeast culture supplement on production, rumen fermentation, and duodenal nitrogen flow in dairy cows. J. Dairy Sci. 75, 3056-3065

Fritche J., Steinhart H., 1998. Analysis, occurrence and physiological properties of trans fatty acid (TFA) with particular emphasis on conjugated linoleic acid (CLA) - a review. Fett/Lipid 8, 190210

Honikel K.O., 1998. Reference Methods for the Assessment of Physical Characteristic of Meat. Meat Sci. 49, 447-457

INRA, 1988. Alimentation ded Bovins Ovins, Caprins. R. Jarrige (Editor). Paris

Jandásek J., Komar M., Minerski M., Ingr I., 2003. Comparison of the contents of intramuscular amino acids in different lamb hybrids. Czech J. Anim. Sci. 48, 301-306

Kłobukowski J., Brzostowski H., Tański Z., Wiśniewska-Pantak D., Sowińska J., 2002. The quality and nutritive value of the meat protein of various lamb genotypes. Pol. J. Food Nutr. Sci. 11/52, $4,41-45$

Lyons P., 2001. A time for answer: solution for the 2001 feed industry. Science and Technology in the Feed Industry. Proceedings of Alltech's $17^{\text {th }}$ Annual Symposium. Nottingham University Press, pp. 1-23 
Masanetz S., Preißinger W.H.H.D. Meyer, Pfaffl M.W., 2011. Effects of the prebiotics inulin and lactulose on intestinal immunology and hematology of preruminant calves. Animal 5, 10991106

Masanetz S., Wimmer N., Plitzner C., Limbeck E., Preißinger W., Pfaffl M. W., 2010. Effects of inulin and lactulose on the intestinal morphology of calves. Animal 4, 739-744

Micklander E., Bertram H. Ch., Marno H., Bak L. S., Andersen H., Engelsen S. B., Norgaard L., 2005. Early post-mortem discrimination of water-holding capacity in pig longissimuss muscle using new ultrasound method. Lebensm.-Wiss. U.-Technol. 36, 1, 125-133

Milewski S., 2006. Health-promoting properties of sheep products Med. wet. 5, 516-519

Milewski S., 2009. Effect of yeast preparations Saccharomyces cerevisiae on meat performance traits and blood hematological indicies in sucking lambs. Med. wet. 65, 51-54

Milewski S., Sobiech P., 2010. Effect of dietary supplementation with Saccharomyces cerevisiae dried yeast on milk yield, blood biochemical and haematological indices in ewes. Bull. Vet. Inst. Pulawy 53, 753-758

Milewski S., Wójcik R., Małaczewska J., Trapkowska S., Siwicki A.K., 2007. Effect of $\beta-1,3 / 1,6-$ D-glukan on meat performance and non-specific humoral defense mechanisms in lambs. Med. wet. $63,360-363$

Oeckel M.J. van, Warnants N., Boucqueé Ch.V., 1999. Comparison of different methods for measuring water holding capacity and juiciness of pork versus on-line screening methods. Meat Sci. 51, 313-320

Patkowska-Sokoła B., Bodkowski R., Jędrzejczak J., 2000. The content of conjugated dienes of linoleic amid in meat and milk of different animal species. Zesz. nauk. AR Wrocław, Konferencje XXX, 399, 257-266

Peisker K.V., 1964. A rapid semi-micro method for preparation of methyl ester from triglycerides using chloroform, methanol, sulphuric acid. J. Amer. Oil Chem. Sci. 41, 87-88

Schieffer G., Scharner E., 1977. Einfluss von Alter, Lebendmasse, Geschlecht und Geburtstyp auf ausgemahlte Qualitätsparameter von Mastlammfleisch. Arch. Tierzucht 20, 129-136

Titi H.H., Dmour R.O., Abdullah A.Y., 2008. Growth performance and carcass characteristics of Awassilambs and Shami goat kids fed yeast culture in their finishing diet. Anim. Feed Sci. Tech. $142,33-43$

Ulbricht T.L.V., Southgate D.A.T., 1991. Coronary heart disease: seven dietary factors. Lancet 338, 985-992 